\title{
Exploring institutional arrangements for local fish product labelling in Tuscany (Italy): a convention theory perspective
}

\author{
Paolo Prosperi ${ }^{*}$ (D), Daniele Vergamini and Fabio Bartolini
}

\author{
*Correspondence: paolo.prosperi@ \\ unipi.it \\ Department of Agriculture, Food \\ and Environment (DISAAA-a), \\ University of Pisa, Via del Borghetto, \\ 80, 56124 Pisa, Italy
}

\begin{abstract}
Increasing fish consumption along with rising competition in the global seafood market has brought fisheries and aquaculture producers to adopt several differentiation and marketing strategies. Labelling schemes were thus introduced to respond to a growing demand for traceable and sustainable products. However, the proliferation of quality labels brought to general confusion, calling for collective and public fish labels to ease decision-making. In our case study region (Tuscany, Italy), a number of policy-driven efforts were deployed for establishing regional labelling schemes for fisheries products with no observable impact on the market. Meanwhile, local companies have implemented a number of successful private and regional labels. The purpose of this research is to contribute to potential options for collective regional labelling schemes of fisheries and aquaculture products, through a case study analysis, building on agro-food value-chain and management approaches. Our empirical results highlight key issues and perspectives on labelling policies for local fisheries and aquaculture products.

Keywords: Fisheries, Aquaculture, Value chain, Quality conventions, Primary producers, Vertical coordination, Eco-labels, Sustainability certifications
\end{abstract}

\section{Introduction}

The increasing globalisation of fisheries and aquaculture supply chains, along with changes in policy regulations, as well as climate change and technological development, are confronting the fishing and aquaculture industries with a wide range of challenges. The rise of fish consumption, along with the increasing competition in the seafood market, has recently brought fisheries and aquaculture producers to adopt differentiation strategies aimed at increasing profits (Grunert 2005). Therefore, the fishing industry has been responding to such increasing consumer demand for traceable and sustainable seafood with the introduction of labelling schemes, thus providing further information on product quality (Morgan et al. 2014). This marketing practice is quite recent for the fish industry (Roheim and Sutinen 2006) and-as a fast-growing voluntary and market-based labelling strategy-is recognized as an important instrument in global environmental fisheries governance (Oosterveer and Sonnenfeld 2012). Thus, new voluntary schemes such as sustainability certifications for sustainable fish and related eco-labels were adopted (de Haes et al. 2010), allowing for credit of the firms'

(c) The Author(s). 2020 Open Access This article is distributed under the terms of the Creative Commons Attribution 4.0 International License (http://creativecommons.org/licenses/by/4.0/), which permits unrestricted use, distribution, and reproduction in any medium, provided you give appropriate credit to the original author(s) and the source, provide a link to the Creative Commons license, and indicate if changes were made. 
engagement to guarantee quality features, to differentiate products from competitors, and to reduce uncertainties on product quality (Riganelli and Marchini 2016).

Concurrently, European policies have repeatedly promoted sustainable fish consumption campaigns, through the Common Fisheries Policy (EU 2011), for stimulating consumers to eat more fish from sustainable sources. In some cases, the proliferation of labelling schemes has brought to general confusion and uncertainty among producers, retailers, and consumers, on how to distinguish a sound certification scheme for fish. Such uncertainty on quality information called for collective and public quality labels for fish, in order to ease decision-making and lessening prices for consumers (European Parliament 2016).

Furthermore, the current increase of eco-labelling schemes for fish is not only justified by consumer demand. In fact, such a growth of eco-labels seems to be strongly connected to retailers' sale promotions and to their commitment to share sustainable practices across the value chain (Gulbrandsen 2006). The collective adoption of those sustainable practices allows coordinated actors (i.e. suppliers and retailers) to better access market (Gulbrandsen 2006) and to improve their reputation. Companies credited with traceability are, in effect, considered a priori more "responsible" for providing products that are safe for consumers and the environment (Mizuta and Vlachopoulou 2017). The efforts implemented by fish suppliers and retailers-to satisfy the increasing market demand of labelled and traceable seafood-have led to further up-scaling and industrialisation the seafood production (Hadjimichael and Hegland 2016).

Thus, to analyse the role of fish quality labels, it appears relevant to go beyond the consumption perspective by exploring how fish labels-initially meant to improve the flow of information between actors to reduce uncertainties on product quality-also express and regulate fish value chain governance and dynamics. According to Marion (2003), within a given value chain, the business-to-business exchanges represent generally the main part of the commercial trade that is often overlooked. Those business-to-business trade exchanges are often characterised by regularity and can, therefore, be defined as institutional arrangements, composed of a set of socioeconomic practices (i.e. habitual, expected, and self-fulfilling behaviours) that are carried out within markets (Marion 2003).

Building on the theoretical basis provided by Marion (2003), in this paper, we argue that the convention theory approach can help understand how those institutional arrangements within value chains are shaped mainly by the role of each actor involved, stimulating additional analyses which go beyond the consideration of the demand. Originally, the convention theory is a theory of production organisation (Salais and Storper 1992). The study of conventions regulating the institutional arrangements between actors allows us to identify and understand the shared principles that enable the agreements between actors and facilitate the flows of information on products exchanged by those ones. In our analysis, we argue that those enabling and shared principles are the building blocks of the fish labels that are adopted across the value chain. In accordance with Gomez (2003), the convention theory approach provides a perspective for a socio-economic interpretation of the interactions between actors that goes beyond contract theories, thus highlighting the relevance of actors' beliefs and principles in order to study emerging and changing economic and market forms of coordination. Furthermore, convention theory has not only been used as a heuristic device to characterise relations, coordination mechanisms, and organisational features, but it has also been applied as a tool to inform firm-level strategy, possible regional—or sectoral-innovation interventions and regulations (Ponte 2016). 


\section{A context-specific challenge for fish labels}

A global perspective on convention theory, applied as a suitable approach through which exploring fish labels as business-to-business arrangements, allows us to better understand and investigate solutions for fish labelling schemes within the regional context of Tuscany (Italy). In our case study region, we have observed that a number of policy-driven efforts (i.e. the regional implementations of the EU Financial Instrument for Fisheries Guidance 2000-2006 and the European Fisheries Fund 2007-2013 ${ }^{1}$ ) have been deployed for promoting and establishing regional and collective labelling schemes for fisheries products (Dintec $2015 \mathrm{a}$ ) with no impact registered on the market yet (to the best of our knowledge $)^{2}$. In fact, the brands for local fish that were proposed and supported by public funding, involved the activity of different types of producers, from small-fishers to well-structured and capital intensive fish farms. Specific market and feasibility studies were produced (Dintec 2015b) to justify the implementation of such a collective labelling initiative. These initiatives aimed at improving the coordination among the local supply chain of fish products, in order to develop a quality label for local fish from capture fisheries and aquaculture. In particular, local actors were meant to be involved in forms of coordination across the valorisation and the promotion of the intrinsic quality characteristics of the local fish by a multitude of perspectives (e.g. organoleptic quality, nutritional aspects, geographical origin, environmental impact, potential for market competition). Those studies mainly included technical aspects about traceability with particular regard to the specification of the fish species and the geographical area of catches. Other important aspects of the analysis were mostly oriented to evaluate potential costs and benefits, due to the implementation of the label, that would concern the actors across the value chain. Also, the interest of consumers and actors for labelled fish, the importance of trademark and promotional activities, as well as the readiness of the stakeholders to adopt the label, were accurately analysed. Former collective fish labelling initiatives and similar current schemes carried out in other Italian regions were also explored for comparison. However, to the best of our knowledge, analysis and observations are lacking with regard to existing forms of coordination within the local fish value chain (including other sorts of existing labels such as private fish brands), that regulate the exchange of information between commercial actors and, thus, determine the related hidden costs and risks for firms. In fact, local fisheries and aquaculture companies in the region of Tuscany have independently-and successfully-adopted and implemented a number of private labels, as well as regional and sustainability brands, especially for retailers. In order to understand what are the attributes of the adopted labels that help to overcome information uncertainties and asymmetries within product exchanges, our research interest is to explore how these tangible marketing strategies explain and originate from upstream business-to-business arrangements.

The next section will present the theoretical background on convention theory in relation with the aims of the paper. Section 3 will describe the methodological approach

\footnotetext{
${ }^{1}$ The three fish labelling projects in Tuscany, supported under the above mentioned European funds, were namely: "Analisi della qualità nella filiera dell'acquacoltura e della pesca nella Provincia di Grosseto e valutazioni preliminari alla costituzione di un marchio collettivo di qualità, etichettatura volontaria e tracciabilità" (project funded in 2004 by Reg. CE n. 1263/99 SFOP 2000-2006 Asse 4 - Misura 4.3); "Realizzazione di uno studio preliminare per la definizione di un marchio della pesca locale" (project funded in 2012 by Reg. CE 1198/2006 FEP 2007-2013 Asse 3 - Misura 3.4); "Studio di fattibilità del marchio e del sistema di tracciabilità/rintracciabilità" (project funded in 2014 by Reg. CE 1198/2006 FEP 2007-2013 Asse 4 - Misura 4.1).

${ }^{2}$ According to our observation of the market and to interviews and regional experts' opinion.
} 
and Section 4 will present the empirical results in terms of the fish labelling schemes we have observed in Tuscany. In the last section, we will discuss our findings by highlighting a number of insights aiming to contribute to the policy discourse on the establishment of collective and local fish labels.

\section{Theoretical background}

In line with Marion (2003), conventions are accepted and shared social constructs that help to cope against uncertainties since they qualify and define the attributes of a product. Therefore, tangible references-such as labels for fisheries and aquaculture products, in our specific case-represent the principles through which it is possible to identify a specific business-to-business convention between primary producers and buyers/retailers.

Convention economics build on the paradigm of uncertainty and on the multiple justifications of action as a result of individuals' and organisations' belongings to different groups such as "worlds" (Rastoin and Ghersi 2010). Ponte (2016) offers an extensive and overarching literature review of the convention theory applied to the food system. In this respect, convention theory helps identifying that there might be multiple justifications of action operating at the same time, and it highlights that different conventions underpin different forms of organisation, coordination, and exchange between actors (Ponte 2016).

The Boltanski and Thévenot's (1999) convention theory model is based on the identification of different worlds of production. This model has been applied to the food system by a number of scholars (e.g.: Murdoch and Miele 1999; Rastoin and Ghersi 2010; Trabalzi 2007) who identified several sets of "world of foods" to explain the strategic positioning of firms and their movements between worlds by highlighting how different worlds of production can coexist even within individual firms (Ponte 2016).

In fact, the food system evolves on a large range of principles, from the market and industrial worlds to the individual/personality world (Rastoin and Ghersi 2010). According to Ponte (2016), the "inspired world" builds on a spiritual, creative, and strongly personally oriented principle-such as the technical-artistic creation of the leading chefs (Rastoin and Ghersi 2010) - that is not possible to certify or formally audit; the "domestic world" involves cultural factors as well as intergenerational transmissions, calling for familyrelated common principles of traditional benevolence, care provision and trustworthiness, and it is characteristic of SMEs and micro-enterprises (Rastoin and Ghersi 2010); the "world of fame" stems from celebrity and public opinion common principle, so that individuals' or firms' merit is achieved when one becomes renowned; the "civic world" is rooted in collective solidarity which is acknowledged and communicated through representative public agency; the "market world" builds on market competition and refers to the price of market goods and services; the "industrial world" builds on the common principle of efficiency as firms focus on functionality and productivity.

Therefore, convention theory offers a structured but pluralistic way of unpacking 'quality'. Since the same agro-food companies may draw on different quality conventions to tap into portfolios of different markets and market segments (Ponte 2016), the convention theory-through a "quality turn" lens-can help explain the strategic positioning of firms and their movement between worlds.

Thus, convention tools represent an information framework that constantly and coherently guarantees actors about the behaviour of the other participants in the convention itself. Actors, such as suppliers and buyers, adopt a convention since they are convinced by 
its principles: this is how a quality convention can be successful. Quality appears, therefore, as the result of collective socio-economic interactions between the actors involved in exchange; the related convention informs value-chain participants about the attributes of a product, the principles, the shared convictions, as well as on the rules justifying their choices for being involved in that convention. As a social construct, a convention limits uncertainties on products and guarantees their functioning not only through a shared acceptance but also through tangible benchmarks (Marion 2003).

Hence, the quality conventions-inspired, domestic, fame, civic, market, and industrial-will help us categorise the key features emerging from our empirical analysis on the adoption and application of the fish labelling schemes. We will then focus on the relations between actors (i.e. suppliers, retailers) characterising the functioning of business-to-business marketing. With respect to the fisheries and aquaculture case of Tuscany, we suggest studying the inter-organisational commercial exchanges to understand the hypotheses that allowed composing a particular quality convention and helped establishing a shared institutional arrangement represented, in turn, by a specific and tangible label. The marketing function is in fact considered key for composing conventions and for making conventions truly convincing; in particular, the study of "labels" can help in this analysis since they can synthetize the convictions that are implicitly shared by both buyers and suppliers (Gomez 2003).

The purpose of this research is to identify and map, for regional fish production, the determinants that influence the implementation and participation of firms in voluntary labelling programs through specific quality conventions and related forms of coordination. Labelling strategies are here considered as expressions of marketing and business-to-business conventions established through shared institutional arrangements and aimed at reducing uncertainties within product exchanges. Through this analysis, we aim at providing policy-making with further insights on the existing adoption of labelling schemes, at a regional level, in order to contribute with further knowledge to potential options for collective regional labelling schemes.

\section{Methods}

This paper applies a qualitative case study approach. A desk-based analysis of the fisheries and aquaculture sectors in Tuscany was combined with a literature review and face-to-face semi-structured interviews with experts and primary producers of the region. Semi-structured interviews were conducted among 3 experts of the fishing industry in Tuscany, 5 representatives of companies (i.e. fishing and aquaculture) and retailers between March and June 2016. The interview sampling was guided by the specific purpose of the paper that relates to a better understanding of the current valuechain dynamics regulating the adoption of fish labels in the Italian region of Tuscany. The selection was guided by the need to find particular cases that can help decisionmakers (i) to improve their knowledge on the current landscape of labelled primary fish products in the region, (ii) to better understand the related forms of coordination and institutional arrangements, and (iii) to develop policy accordingly. Interviews transcripts were then analysed building on the tenets and on the approaches of the quality convention theory as it has been described in the previous sections of this paper (Sylvander 1995; Boltanski and Thévenot 1999; Gomez 2003; Marion 2003; Ponte and Gibbon 2005; Ponte 2016). 


\section{Case study region and business environment}

Tuscany is a region in west-central Italy, with a coastline on the Ligurian Sea (in the north) and on the Tyrrhenian Sea (in the south). With regard to marine capture fishing in Tuscany, according to the Italian Ministry of Agricultural, Food and Forestry Policies (MIPAAF, 2011), in 2011, the production was estimated at almost 41 million $€$ in revenues. The incidence of Tuscan fishing production on the national total reaches a market share of about $4.5 \%$. Fish production belongs mainly to the bluefish category. The most important port is Livorno and the fishing activity is spread among 27 ports with 600 registered fishing vessels and 1053 active fishers in 2015 (FAO 2018).

Concerning the fishery market potential in the region, it is worth mentioning that the fishery business sector, for primary production, is strongly fragmented. Small-scale fisheries are dispersed in several harbours and vulnerable because of individualism, as well as for the strong specialisation of the fishing activity related to the ecological characteristics of the fishing area. There is also a growing competition between small-scale and trawling fisheries, because of lack of resources and infrastructures. Small-scale fisheries compose almost $75 \%$ of the Tuscan fisheries. The number of vessels has been strongly decreasing in the last two decades (-22.5\% in the period 1999-2011) (PSL-GAC Toscana 2015) mainly as a result of the Common Fisheries Policy commitment to reduce the European fleet capacity (Sabatella and Spagnolo, 2011). Concurrently, since the 2007-2008s financial crisis, the number of vessels has been further decreasing every year. Small-scale fishers adopt strategies related to product and sale differentiation, as well as to multifunctionality (Prosperi et al. 2019). According to experts' and local actors' opinion, with regard to trawlers and purse seiners, there is an increase of horizontal coordination in order to concentrate the offer on the market. External and cheaper markets-such as important national harbours (e.g. Ligurian and Adriatic ports) or import from foreign countries-represent relevant factors of competition for local fish production. Regional policies, supported by specific European funds, have been implementing a number of supportive measures such as (i) promoting the area and its local fisheries products (i.e. the collective labelling scheme mentioned above), (ii) strengthening the links between fishing activities and tourism, (iii) developing vocational training for fishers, and (iv) adding value to production through the development of new forms of marketing (EC-FARNET 2014; PSL-GAC Toscana 2015).

With regard to saltwater aquaculture and mariculture, Tuscany occupies an important position in terms of quality and quantity for the production of valuable marine species (over $20 \%$ of national production), with mainly 12 aquaculture and 4 mariculture coastal installations that mostly farm sea bream and sea bass. The farms that use marine water or brackish water are all located in the provinces of Livorno and Grosseto (Gilmozzi 2011). The production value, mainly obtained from sea bass and sea bream, achieved almost 25 million $€$ in 2010 (PSL-GAC Toscana 2015). In the region, the number of aquaculture firms has been decreasing together with the consolidation of the biggest ones. European policies have funded the technological assets of aquaculture producers while regional policies have been restricting the extension of mariculture activities that are extremely regulated. However, the regional policies have recently allowed new expansion of aquaculture production in limited areas of the Tuscan marine waters (Bartolini et al. 2018).

In 2013, the total production value of the fisheries and aquaculture sector in Tuscany has reached 72.89 million euro while the added value was equal to 38.08 million euro 
(Dintec 2015a). According to the Italian National Institute of Statistics, Tuscany is a net importer of fishery products and aquaculture while the exports in 2013 only exceeded 4 million $€$ (Dintec 2015a). This trend of import is consistent with the national consumption trends in Italy. While Italian consumers are generally considered sensitive to the local origin of the fish consumed, the national demand for fresh and processed seafood depends on import for 73\% (ISMEA 2011), and big retailers are the most important supply channels for consumers (ISMEA 2018).

\section{Results}

\section{Labelling schemes for local fish production}

Within the described business context, and according to our field research and expert opinion, the most capital intensive and structured fishery and aquaculture enterprises in Tuscany are increasingly supplying big retailers with own brands and labels that mainly refer to regional and local contexts. Such tangible benchmarks are the results of well-rooted business-to-business interactions.

For example, some labelling schemes are tangible benchmarks of established marketing strategies of aquaculture producers that are historically characterised by more structured and capital-intensive businesses than the companies of the fishery sector. In addition to own local brands, some aquaculture firms adopted international sustainability labels (e.g. Friend of the sea) and others were involved in regional product labelling schemes (e.g. Slow Food Presidia). According to interviews with local fish farmers, these qualitylabelling schemes-together with a strong and constant fish supply capacity as well as a historical capability of creating partnerships between enterprises-allow Tuscan aquaculture producers to enter the big retailing system with medium-high price products (i.e. the labelling schemes guarantee higher sale prices).

From our empirical analysis on labelling schemes, different strategies (observed in the market and reported from our field research based also on local stakeholders' and experts' opinion) were mapped for both fresh and processed fisheries and aquaculture products from Tuscany. Those strategies were analysed as marketing business-tobusiness interactions that are recognisable through a tangible benchmark. The labelling schemes, adopted to sell fish caught or farmed in Tuscany, are mainly composed of own producers' brands and eco-labels.

We have observed that own brands can be implemented either by primary producers' organised groups or by wholesalers in coordination with big retailers through domestic quality conventions. On the other hand, eco-labels can be adopted by producers' groups in coordination with NGOs and big retailers-through the implementation of civic quality conventions-and they are represented by certifications of sustainability and regional product labels. Big retailers are involved in all labelling schemes observed, both as coordinating actors and market targets, while wholesalers participate only in territory-driven labelling schemes. Table 1 helps depict the main types of labelling schemes identified in our case study region, the driving quality conventions (domestic and civic), as well as the role of actors involved and the market targeted by the labelling strategies. The next two sections will further explain the functioning of the two groups of labelling schemes identified, classified as "own brands" and "eco-labels". 
Table 1 Key features related to the labels adopted and the related quality conventions

\begin{tabular}{|c|c|c|c|c|c|c|}
\hline $\begin{array}{l}\text { Labelling } \\
\text { scheme }\end{array}$ & $\begin{array}{l}\text { Quality } \\
\text { convention }\end{array}$ & Suppliers & $\begin{array}{l}\text { Label } \\
\text { exclusivity }\end{array}$ & $\begin{array}{l}\text { Actors } \\
\text { involved }\end{array}$ & Products & $\begin{array}{l}\text { Target } \\
\text { market }\end{array}$ \\
\hline $\begin{array}{l}\text { Producers' } \\
\text { own brands }\end{array}$ & Domestic & $\begin{array}{l}\text { - } 1 \text { aquaculture } \\
\text { consortium } \\
\text { (3 firms) } \\
\text { - } 1 \text { aquaculture } \\
\text { firm } \\
\text { - } 1 \text { cooperative of } \\
\text { lagoon fisheries } \\
\text { and aquaculture }\end{array}$ & Producer/s & $\begin{array}{l}\text { - Producers } \\
\text { and } \\
\text { consortia } \\
\text { (suppliers) } \\
\text { - Quality } \\
\text { auditors (for } \\
\text { big retailers) }\end{array}$ & $\begin{array}{l}\text { - Fresh fish } \\
\text { - Processed } \\
\text { seafood } \\
\text { - Aquaculture } \\
\text { and lagoon } \\
\text { fisheries }\end{array}$ & $\begin{array}{l}\text { - Big retailers } \\
\text { - Wholesalers }\end{array}$ \\
\hline $\begin{array}{l}\text { Wholesalers' } \\
\text { brands }\end{array}$ & Domestic & $\begin{array}{l}\text { - } 1 \text { wholesaler of } \\
\text { capture fisheries } \\
\text { - } 1 \text { fishery and } \\
\text { trade firm }\end{array}$ & $\begin{array}{l}\text { Wholesalers, } \\
\text { big retailers }\end{array}$ & $\begin{array}{l}\text { - Primary } \\
\text { producers } \\
\text { (fishers) } \\
\text { - Wholesalers } \\
\text { (suppliers) } \\
\text { - Big retailers } \\
\text { - Quality auditors }\end{array}$ & $\begin{array}{l}\text { - Fresh fish } \\
\text { - Processed } \\
\text { seafood } \\
\text { - Capture } \\
\text { fisheries } \\
\text { (trawlers and } \\
\text { small-scale) }\end{array}$ & - Big retailers \\
\hline $\begin{array}{l}\text { Sustainability } \\
\text { certifications }\end{array}$ & Civic & $\begin{array}{l}\text { - } 1 \text { aquaculture } \\
\text { consortium } \\
\text { (3 firms) }\end{array}$ & $\mathrm{NGO}$ & $\begin{array}{l}\text { - Producers and } \\
\text { consortia } \\
\text { (suppliers) } \\
\text { - Big retailers } \\
\text { - NGO } \\
\text { - Quality auditors }\end{array}$ & $\begin{array}{l}\text { - Fresh fish } \\
\text { - Aquaculture }\end{array}$ & - Big retailers \\
\hline $\begin{array}{l}\text { Regional } \\
\text { products }\end{array}$ & Civic & $\begin{array}{l}\text { - } 1 \text { cooperative of } \\
\text { lagoon fisheries } \\
\text { and aquaculture }\end{array}$ & $\mathrm{NGO}$ & $\begin{array}{l}\text { - Producers' } \\
\text { organisation } \\
\text { (suppliers) } \\
\text { - Big retailers } \\
\text { - NGO }\end{array}$ & $\begin{array}{l}\text { - Processed } \\
\text { seafood } \\
\text { - Lagoon } \\
\text { fisheries } \\
\text { (mainly) and } \\
\text { capture } \\
\text { fisheries }\end{array}$ & - Big retailers \\
\hline
\end{tabular}

\section{Own brands}

A number of fish labelling strategies in Tuscany were observed in the market and categorised as own brands for both aquaculture and fisheries production. An own private brand is an independent brand that indicates the supplier and the geographical area of production. Own brands in Tuscany are implemented mainly by aquaculture producers (companies or producers' organisations), by traditional lagoon fishers joint in a cooperative, by consortia of fishers and fishing cooperatives, as well as by fish wholesalers in coordination with big retailers.

\section{Domestic convention-driven own-brands for primary products of fisheries and aquaculture}

\section{in Tuscany}

Producers' own brands. Producers' own brands for primary fish products in Tuscany relate mainly to business-intensive aquaculture and to traditional lagoon fisheries' businesses. Those brands are implemented for sales to wholesalers and retailers. Producers' own brands are tangible benchmarks directly identifying the primary producers' firm, or organisation of firms such as consortia, and express a domestic convention across the value chain-from the upstream supplier level to the downstream consumer level. Suppliers identify their own products in the specific geographical context in which their reputation is acknowledged. They refer to these quality characteristics with retailers who, in turn, keep those tangible references visible in order to communicate to consumers the origin and quality of fish products. Especially for aquaculture, those 
domestic conventions are often reinforced through industrial coordination, under the requirement of specific certifications (i.e. ISO) demanded by the retailers.

Wholesalers' own brands. Wholesalers' brands for primary fish products in Tuscany relate mainly to spontaneous and independent initiatives of well-structured fishers and wholesalers, organised in different forms of coordination-such as consortium and cooperatives-in order to sell local fish to big retailers in the region. Two relevant examples of wholesalers' brands for fish in Tuscany are represented by "Consorzio Ori del Mar Tirreno"-for sales to the retailer Conad-and "P.A.T. Pescato nell'Arcipelago Toscano"-for sales to the retailer Unicoop Firenze. These brands are the expression of a domestic convention based on the geographic origin of the fish caught, on the reputation of the suppliers at a local level, as well as on the value chain actors' capacity to provide local and fresh fish, guaranteeing the quantity levels and quality characteristics required by the retailers. In some particular cases, such as for "P.A.T. Pescato nell'Arcipelago Toscano", the domestic convention is reinforced by industrial coordination through the requirement of quality and origin certifications that are guaranteed by a third actor such as the independent certification body "CSQA". In other cases, such as for the "Consorzio Ori del Mar Tirreno", a product specification is directly agreed between supplier and retailer, with the retailer owing the exclusivity of the brand, and the wholesaler providing information and traceability about quality and origin of the fish supplied. For wholesalers' brands, the label is a tangible benchmark applied across the value chain, characterising both the business-to-business coordination between suppliers and retailers as well as the marketing communication with the consumers.

All producers' and wholesalers' brands are adopted for selling mainly to big retailers and provide information on the geographical indication, as well as on the primary production company's name (e.g. for aquaculture and lagoon fisheries products). Since the identity and quality of products are ensured and "institutionalised" by the contextspecific geographical origin, by long-term relationships between actors (including their role in the local network), and by the companies' private brands, such labelling strategy is identifiable within the domestic conventions (Boltanski and Thévenot 1999; Ponte and Gibbon 2005).

However, the "domestic coordination", described by the adoption of own brands, is reinforced by "market coordination", "industrial coordination" and "civic coordination"-depending respectively on the market target, on the characteristics of the supplier, as well as on the typology of production. For instance, according to Boltanski and Thévenot's (1999), in our specific context we are able to acknowledge that domestic coordination is coexisting with market coordination since both fisheries and aquaculture products labelled with own brands are actually exchanged between the most important buyers (big retailers) and sellers of the regional market through competitive relationships. Similarly, domestic coordination comes along with industrial coordination since-according to convention theory (Sylvander 1995; Boltanski and Thévenot 1999; Renard 2003)-industrial coordination takes place when common norms and standards are objectively determined and measured through appropriate control processes and tools. In fact, in our case study, all aquaculture companies and some marine fish suppliers, sell their branded products to big retailers under the accreditation of standards 
(ISO) or other quality certifications, operated by third parties, to strengthen information and lessen uncertainty on product quality. In other cases, own brands can certify an agreed internal protocol, signed between the partners of the producer organisation (e.g. cooperatives, consortia, etc.), that guarantees the control of quality all over the production and retail process (see the next two subsections below for empirical examples). Some of the abovementioned own brands are also reinforced by the concurrent engagement of the producers in a "civic-coordination", as it will be described in the eco-labels' subsection of this paper.

\section{Eco-labels}

Eco-labelling is basically a private, voluntary, market-based tool, complementary to public policy instruments, that provides environmental information to products in order to influence market behaviour. These tools encourage the behavioural change of producers and consumers towards long-term sustainability and allow selecting products and services according to specific environmental and social criteria. Eco-labels are acknowledged to contribute to the resilience of local food systems to environmental loss (Allen et al. 2019). In our case study analysis-according to de Haes et al.'s classification (de Haes et al. 2010)-we have identified in the market two eco-labelling schemes related to sustainability certifications of natural resources and to regional products: (i) sustainability certifications that function as marketing tools, protecting and improving the value of the brand or supermarket chain; (ii) regional products that stem from a well identifiable region, referring to various quality aspects, to a focus on gastronomy, to traditional techniques, and to the employment of human resources (also attention for the environment is more and more associated with regional products).

Civic convention-driven eco-labels for primary products of fisheries and aquaculture in Tuscany

International sustainability certifications (Friend of the sea). The adoption of international certifications of sustainability for fish products in Tuscany relates exclusively to the "Friend of the Sea" scheme and, thus, to sales to big retailers. In our specific case, three aquaculture firms have joined in a consortium that adheres to the sustainable production practices required by the NGO that is responsible for the certification scheme (Friend of the Sea). Retailers require that local suppliers (i.e. the primary producers' consortium) provide "sustainably" certified products and, in parallel, they ask producers for controlling the product quality through standard audits. Then, retailers involve those certified fisheries products within their set of "quality-controlled products". In this way, retailers embed the quality and sustainability factors of suppliers in their value chain. In this case, the "Friend of the Sea" label remains a "marketing business-to-business tool"-i.e. the expression of a civic convention between supplier and producer-that is not explicitly translated to the final consumers. The information transferred to consumers is embedded and guaranteed by the retailers and involves a number of implicit principles and beliefs, characterising the interactions between suppliers, NGO, and retailers, that in turn are reinforced by industrial relationships (i.e. auditing, biological and chemical controls, adoption of ISO standards). 
Regional products' labels (Slow Food Presidia). Slow Food Presidia for fish products in Tuscany relate mainly to small-scale fisheries and traditional lagoon fisheries. In particular, a fishing cooperative-composed of 48 lagoon fishers-adopted three different Slow Food Presidia. A number of specific products of the cooperative are required by the NGO (Slow Food) to comply with particular traditional and sustainable production practices (building on an agreed product specification). The cooperative supplies with these labelled products only specific retailers who acknowledge and demand their labelled products (e.g. Eataly, Coop Italia, Conad). The Slow Food Presidia label is adopted by the cooperative and characterises the institutional arrangement the cooperative ties with the retailers who contributed to the constitution of the label (Coop Italia), as well as with those retailers who explicitly support traditional and local food systems (Eataly). In this case, the Slow Food label does not represent only a marketing tool of a business-to-business coordination, but it also constitutes a tangible benchmark-visible to consumers-that defines the shared convention between actors from the upstream to the downstream, thus including the primary producers joint in the cooperative, the NGO, and the retailers. From our analysis, it emerged that territorial capital and traditional capital were key for the cooperative to enter the certification scheme, and so to adopt the label building on the story of this kind of production and on the acknowledgement of the traditional practices.

The adoption of eco-labels can be considered as an expression of civic conventions, rooted in collective solidarity and commitment to common social and environmental welfare-acknowledged and communicated through a representative public agency. Relationships with retailers are characterised by distributional arrangements and negotiation that also consider-as quality factors-the social, labour, environmental and collective impacts (e.g. the high-quality feed for fish). As for the aforementioned domestic conventions, also the civic conventions analysed in our case study are reinforced and interact with other forms of coordination, depending on the supplier characteristics and on the buyers. In our specific case study, the large production capacity of the suppliers who adopt eco-labels allows providing retailers with relevant quantities in the requested time frame. According to Boltanski and Thévenot (1999), such "market coordination" is possible between acknowledged important actors of the local market in a "deal-making" dynamic (Ponte 2016). Moreover, it represents a fundamental competitiveness tool for the firms to face international market competition (especially from Greek producers in the case of sea bass and sea bream from aquaculture). Furthermore, since certifications of sustainability for fisheries products (e.g. Marine Stewardship Council, Friend of the Sea, etc.) are tested through standardised methods and are requested by retailers together with complementary standard certifications (e.g. ISO), then "industrial coordination" is also strongly associated with eco-labels adoption, strengthening the organisational principles based on productivity and efficiency. In our case study, we have also observed that big retailers brand eco-labelled fish products, provided by suppliers, with their own quality labels (i.e. with the retailer brand), thus embedding the quality and sustainability of suppliers in their value chain.

\section{Discussion and conclusions}

With the aim of providing local policies with insights regarding the fish labels' governance, a number of private quality labels for local primary products of fisheries and 
aquaculture in Tuscany were observed in the market and mapped to explore the conventions embedded upstream and characterising the business-to-business relationships between fish suppliers and retailers. From this theoretical and empirical case study analysis, we have showed how sustainability certifications and regional products' eco-labels (observed in the regional market) function as business strategic tools for conventional marketing to compete in large-scale retailing, reducing uncertainties between actors, and targeting medium-high prices. Besides eco-labelling, firms implement ownlabelling strategies, building mainly on the territorial context characteristics and on reputation.

The observation of the coexistence of different forms of coordination in the local fish supply chain-depending on the end-market and the exchange partners-has confirmed previous and acknowledged findings from convention theory (Ponte and Gibbon 2005). In particular, it emerged that both civic and domestic conventions-as in previous fundamental examples (i.e. Thévenot 1995; Ponte 2016) - are embedded in marketindustrial compromises. From a supplier point of view, these coordination coexistences and compromises-together with the inclusion of external actors (e.g. external parties, NGOs, auditors) - are considered key for guaranteeing a qualitatively and quantitatively appropriate supply to big retailers. Concurrently, our context-specific findings have confirmed previous empirical observations of other scholars who had observed, in other food business contexts, that the reinforcement through an industrial convention can finally endorse and sustain civic elements (Riisgaard and Gibbon 2014; Ponte 2016).

Our empirical results allow identifying some key issues to consider for delivering policy lines about labelling schemes and voluntary certifications for fisheries and aquaculture products of Tuscany. The convention theory approach has highlighted the relevance of a selective phase that actors have to come through for interacting within a specific convention, as well as the importance of the benchmarks, through labelling, in reinforcing the principles of a convention and reducing uncertainties through the value chain. Then, as already confirmed by Marion (2003), each convention is characterised by specific competencies, interpersonal contacts, personal acknowledgment between actors, specific places for business activity, decision-making, and interactions.

From our context-specific analysis of fish labels, it emerged that at a regional level in Tuscany, in most cases, labelling schemes are quality control schemes implemented by the suppliers and requested by the retailers. In these cases, suppliers bear the costs of the quality controls and such labelling schemes are essentially business-to-business marketing tools, so that the intrinsic information on the quality or sustainability of the products is not transferred directly to final consumers, but is rather embedded in the quality schemes of the retailers. Therefore, fish labels-as other quality, sustainability or place brands-are often strategic marketing tools that imply relevant costs and organisational efforts for the firms that adopt or implement them. Especially with regard to the fishery sector, small-scale fishers can hardly afford those certifications that remain rather an exclusivity of few large enterprises controlling the market (Mizuta and Vlachopoulou 2017). Also, labelling initiatives originated from capital-intensive productions can have a strong impact on the diversity of a specific commodity market (Hadjimichael and Hegland 2016). Thus, small-scale fisheries have to adopt different strategies to be competitive in the market, and this was in part one of the main aims of the policy-driven efforts promoted in Tuscany for a local and collective fish-labelling 
scheme (as described above). Being food products' labels a tool that involves complex coordination dynamics often oriented towards big retailers, the integration of small producers presents several difficulties.

\section{Lessons learnt}

- Before implementing new fish labels at a regional level, it is worth considering that the central role played by big retailers in vertical coordination with suppliers for adopting quality labels and distributing labelled products. In Tuscany, existing quality-labelling schemes for fish products are, in fact, managed by non-state actors and both suppliers and retailers bear costs in order to lessen information asymmetries within the value chain and, possibly, to improve quality knowledge for consumers. Generally, guaranteeing and providing food quality information is an inherently costly activity for suppliers (Antle 2001). Also, new tangible marketing tools such as labels need to be conceived as pertinent expressions of a business-tobusiness convention, not only for targeting final consumers.

- Convention theory helped understand that both civic and domestic labelling agreements actually need to be supported by complementary forms of coordination (e.g. industrial and market forms).

- The main existing labelling efforts observed are oriented to reduce uncertainties and to improve information on sustainable practices and local fish production that can be deemed as relevant opportunities for a new quality scheme. However, such organisation implies a well-established qualitative and quantitative coordination between actors building on industrial approaches-such as quality and traceability controls-for responding to the retailing demand of labelled products with appropriate quantity in limited time. An additional labelling and certification scheme would imply further investment and costs (Banterle and Stranieri 2008), a rearrangement of inter-firm coordination, cooperation, trust and fidelity, as well as the capacity of building a new quality convention made of shared principles. Furthermore, for product procurement, retailers refer to particular lists of suppliers that are difficult to integrate especially for fishers who are not belonging to an acknowledged group of producers.

- Similarly as observed from other scholars on collective "place brands" of food products (Donner et al. 2014; Donner et al. 2017), a more holistic consideration of context-specific coordination, institutional interactions, partnerships and anchorage of actors within a particular territory, seems to be key to support the success of local labelling schemes in rural areas, going beyond consumer analysis.

- Innovations in local marketing (such as the introduction of new labelling schemes at a local level) are rather the result of collective and iterative works obtained through a combination of traditions and previous practices, often inherited by previous collective experiences. A new marketable element is often the outcome of a shared sociotechnical context always inspired by a previous experience (Marion 2003). Thus, beyond proposing new labels, public policies (aimed at generating and capturing value added for fisheries and aquaculture primary producers) could enable local producers with improved skills to join existing and successful labelling schemes. Also, it was 
observed that label adoptions stem from business environments characterised by forms of horizontal coordination, such as cooperatives and consortia, and vertical integration. Thus, since the adoption of quality labels is currently possible only for a reduced number of producers, it could be fostered not only through supporting investments in technical and marketing training but also through enhancing the coordination and cooperation capacity of producers within the value chain.

- Furthermore, since our context-analysis analysis has highlighted that labelling schemes are adopted only by well-structured and organised producers, improving infrastructures and logistics for the fisheries and aquaculture sector in Tuscany could contribute to reduce transaction costs, to avoid uncertainties through the value chain and to help coordination and cooperation between actors of the value chain.

- As it already emerged, fish labelling strategies could be considered as marketing and coordination tools for industrial economic and production models, mainly because of costs, organisation and capital structure needed. Thus, local policies oriented to support small-fisheries needs could shift from encouraging these marketing tools that are typical of large-scale forms of competition, to targeting instead novel strategies and new economic models for small-scale fishers, as well as to supporting more focused entrepreneurial skills as it emerged from previous researches on local fisheries in this area (Prosperi et al. 2019).

- The role of big retailers with regards to eco-labels and the role of wholesalers with regard to firms' own label are worth considering. From this analysis, it is difficult to identify room for other labels unless there is an involvement of wholesalers and big retailers keen to drive further production for answering consumer demand.

- Finally, to introduce a new fish label at a local level, it is important to distinguish between aquaculture and fishing activity, as well as considering the intensity of capitals and the level of the business activity of the producers involved in the existing labelling schemes in Tuscany.

In conclusion, despite our findings are limited to a geographical region, the contextspecific analysis of fish labelling schemes through the convention theory can contribute to frame further analyses towards the understanding of challenges and opportunities for fisheries and aquaculture labelling schemes and related institutional arrangements at different scales.

\section{Acknowledgements}

This work was developed within the EU project SUFISA "Sustainable finance for sustainable agriculture and fisheries" (Horizon 2020 Grant agreement 635577).

This paper has been selected as one of the best papers of the First joint SIDEA-SIEA Conference in Bisceglie/Trani (1316 September 2017). It has been accepted for publication in this journal following the usual review process.

\section{Authors' contributions}

Study conception and design by PP. Review and acquisition of data/material by PP. Analysis and interpretation by PP, DV, FB. Drafting of manuscript by PP. Review and comments by DV, FB. All authors read and approved the final manuscript.

Funding

This work was funded by the EU project SUFISA "Sustainable finance for sustainable agriculture and fisheries" (Horizon 2020, Grant agreement 635577). 


\section{Competing interests}

The authors declare that they have no competing interests.

Received: 20 August 2018 Accepted: 14 January 2020

Published online: 30 January 2020

\section{References}

Allen T, Prosperi P, Cogill B, Padilla M, Peri I (2019) A delphi approach to develop sustainable food system metrics. Soc Indic Res 141: 1307-1339. Available via DIALOG. https://doi.org/10.1007/s11205-018-1865-8 Accessed 20 Dec 2019.

Antle JM (2001) Economic analysis of food safety. In: Gardner BL, Rausser GC (eds) Handbook of Agricultural Economics. Elsevier Science, Amsterdam, London, New York

Banterle A, Stranieri S (2008) Information, labelling, and vertical coordination: an analysis of the Italian meat supply networks. Agribusiness 24:320-331

Bartolini F, Brunori G, Grando S, Minarelli F, Prosperi P, Raggi M, Viaggi D, Vergamini D (2018) SUFISA National Report: Italy. Available via DIALOG www.sufisa.eu/wp-content/uploads/2018/10/D_2.2-Italy-National-Report.pdf Accessed 20 Dec 2019.

Boltanski L, Thévenot L (1999) The sociology of critical capacity. Eur J Soc Theory 2:359-377

de Haes HU, de Snoo GR, Sonesson U, Berlin J and Ziegler F (2010) Eco-labelling of agricultural food products. In: Sonesson U, Berlin J, Ziegler (eds) Environmental Assessment and Management in the Food Industry: Life Cycle Assessment and Related Approaches. Woodhead Publishing, Philadelphia.

Dintec (2015a) Marchio collettivo "Costa Toscana": Mappatura delle esperienze e analisi del settore e della filiera ittica in Toscana. CCIAA, Grosseto, Italy. Available via DIALOG. www.gr.camcom.gov.it/moduli/output_immagine.php?id=2898 Accessed 02 Aug 2018.

Dintec (2015b) Marchio collettivo "Costa Toscana": Analisi di sostenibilità organizzativa ed economica. CCIAA, Grosseto, Italy. Available via DIALOG. www.gr.camcom.gov.it/moduli/output_immagine.php?id=2897 Accessed 02 Aug 2018.

Donner M, Fort F, Vellema S (2014) How to capture place brand equity? The case of Sud de France. Place Branding and Public Diplomacy 10:145-157

Donner M, Horlings L, Fort F, Vellema S (2017) Place branding, embeddedness and endogenous rural development: Four European cases. Place Branding and Public Diplomacy 13:273-292

EC-FARNET (2014) FLAG factsheet—Italy—Coast of Tuscany. Available via DIALOG. https://webgate.ec.europa.eu/fpfis/cms/ farnet/it/flagsheet/flag-factsheet-italy-coast-tuscany Accessed 24 Aug 2019.

European Commission (2011) Fisheries and Aquaculture in Europe. No 53, October 2011. European Commission publication Directorate-General for Maritime Affairs and Fisheries, Brussels. Available via DIALOG. http://aei.pitt.edu/86752/1/53.pdf Accessed 02 Aug 2018.

European Parliament (2016) Research for PECH Committee-Small-scale fisheries markets: value chain, promotion and labelling. European Commission, Directorate-General for internal policies, Brussels. Available via DIALOG. http://www. europarl.europa.eu/RegData/etudes/STUD/2016/573443/IPOL_STU(2016)573443_EN.pdf Accessed 02 Aug 2018.

FAO (2018) Fishery and Aquaculture Country Profiles: The Republic of Italy. www.fao.org/fishery/facp/ITA/en Accessed 02 Aug 2018.

Gilmozzi M (2011) Aquaculture: Tuscany. In Cataudella, S. and Spagnolo, M. (eds.) The State of Italian Marine Fisheries and Aquaculture. Rome, Italy: Ministero delle politiche agricole alimentari e forestali, pp. 295-297. Available via DIALOG. https://www.politicheagricole.it/flex/cm/pages/ServeAttachment.php/L/IT/D/d\%252F6\%252Fe\%252FD.d185167b6a9b6393 d9f2/P/BLOB\%3AID\%3D6412/E/pdf Accessed 24 Aug 2019.

Gomez P-Y (2003) Préface. In: Amblard M (ed) Conventions et Management: Editions De Boeck. Louvain-la-Nouvelle, Belgium

Grunert KG (2005) Food quality and safety: consumer perception and demand. Eur Rev Agric Econ 32:369-391

Gulbrandsen LH (2006) Creating markets for eco-labelling: are consumers insignificant? Int J Consumer Stud 30:477-489

Hadjimichael M, Hegland TJ (2016) Really sustainable? Inherent risks of eco-labeling in fisheries, Fish Res 174:129-135

ISMEA (2011) II pesce a tavola: percezioni e stili di consumo degli Italiani. ISMEA, Rome. Available via DIALOG http://www. ismea.it/flex/cm/pages/ServeAttachment.php/L/IT/D/f\%252Fb\%252F5\%252FD.914a4f340b52602fcc38/P/BLOB\%3AID\%3 D6191/E/pdf Accessed 02 Aug 2018.

ISMEA (2018) Osservatorio settore ittico - Consumi. Ismea, Rome. http://www.ismea.it/flex/cm/pages/ServeBLOB.php/L/IT/ IDPagina/9708\#id-fff1d02987191c962e35c623b0fa5c1f Accessed 02 Aug 2018.

Marion G (2003) Le marketing et les conventions de qualification: une première synthèse. In: Amblard, M. (ed.) Conventions et Management. Louvain-la-Nouvelle, Belgium: Editions De Boeck, pp. 27-59.

MIPAAF (2011) Lo stato della pesca e dell'acquacoltura nei mari italiani. MIPAAF, Rome. Available via DIALOG. https://www. politicheagricole.it/flex/cm/pages/ServeBLOB.php/L/IT/IDPagina/5164 Accessed 02 Aug 2018.

Mizuta DD, Vlachopoulou El (2017) Satoumi concept illustrated by sustainable bottom-up initiatives of Japanese Fisheries Cooperative Associations. Mar Policy 78:143-149

Morgan R, Lesueur M, Henichart LM (2014) Fisheries diversification: a case study of French and English fishers in the Channel. In: Urquhart J, Acott TG, Symes D, Zhao M (eds) Social Issues in Sustainable Fisheries Management. Springer, Dordrecht, Heidelberg, New York, London.

Murdoch J, Miele M (1999) 'Back to nature': changing 'worlds of production'in the food sector. Sociol Ruralis 39:465-483

Oosterveer P, Sonnenfeld DA (2012) Food, globalization and sustainability. Routledge, London

Ponte S (2016) Convention theory in the Anglophone agro-food literature: Past, present and future. J Rural Stud 44:12-23

Ponte S, Gibbon P (2005) Quality standards, conventions and the governance of global value chains. Econ Soc 34:1-31

Prosperi P, Kirwan J, Maye D, Bartolini F, Vergamini D, Brunori G (2019) Adaptation strategies of small-scale fisheries within changing market and regulatory conditions in the EU. Mar Policy 100:316-323

PSL-GAC Toscana (2015) Piano di Sviluppo Locale del Gruppo di Azione Costiera "Costa di Toscana". Regione Toscana, Florence, Italy. Available via DIALOG. http://www.regione.toscana.it/documents/10180/11802128/Delibera_n.643_del_1805-2015-Allegato-A.pdf/c8ca52ae-3624-4a73-a89a-67b6b76a0f15 Accessed 24 Aug 2019.

Rastoin JL, Ghersi G (2010) Le système alimentaire mondial: concepts et méthodes, analyses et dynamiques. Éditions Quae, Paris 
Renard MC (2003) Fair trade: quality, market and conventions. J Rural Stud 19:87-96

Riganelli C, Marchini A (2016) The Strategy of Voluntary Certification in Italian Olive Oil Industry: Who and Why? Recent Pat Food Nutr Agric 8:9-18

Riisgaard L, Gibbon P (2014) Labour management on contemporary Kenyan cut flower farms: foundations of an industrialcivic compromise. J Agrar Change 14:260-285

Roheim CA, Sutinen JG (2006) Trade and marketplace measures to promote sustainable fishing practices. International Centre for Trade and Sustainable Development and the High Seas Task Force, Geneva.

Salais R, Storper M (1992) The four 'worlds' of contemporary industry. Cambridge J Econ 16:169-193

Sylvander B (1995) Conventions de qualité et institutions: le cas des produits spécifiques. In: Valceshini E, Nicolas F (eds) Agro-alimentaire: une économie de la qualité. INRA-Economica, Paris, pp 167-184

Thévenot L (1995) Des marchés aux norms. In: Allaire G, Boyer R (eds) La grande transformation de l'agriculture: Lectures conventionnalistes et régulationnistes. INRA-Economica, Paris, pp 33-51

Trabalzi F (2007) Crossing conventions in localized food networks: insights from Southern Italy. Environ Plann A 39:283-300

Sabatella RF, Spagnolo M (2011) National planning and management measures: Fishing effort management and rights of ownership in national intervention policies. In Cataudella, S. and Spagnolo, M. (eds.) The State of Italian Marine Fisheries and Aquaculture. Rome, Italy: Ministero delle politiche agricole alimentari e forestali, pp. 379-384. Available via DIALOG. https://www.politicheagricole.it/flex/cm/pages/ServeAttachment.php/L/IT/D/d\%252Ff\%252F5\%252FD.d400f62a0f179e8e64 75/P/BLOB\%3AID\%3D6412/E/pdf. Accessed 24 Aug 2019.

\section{Publisher's Note}

Springer Nature remains neutral with regard to jurisdictional claims in published maps and institutional affiliations.

\section{Submit your manuscript to a SpringerOpen ${ }^{\circ}$} journal and benefit from:

- Convenient online submission

- Rigorous peer review

- Open access: articles freely available online

High visibility within the field

- Retaining the copyright to your article 